\title{
GENDER CHANGE OF TRANSSEXUALS IN SHARIAH: AN ANALYSIS
}

\author{
Zahra Sarcheshmehpour \\ Ph.D Candidate, Department of Shariah and Law, \\ Academy of Islamic Studies, \\ University of Malaya, 50603 Kuala Lumpur. \\ zsarcheshmehpoor@yahoo.com \\ Raihanah Hj. Abdullah \\ Professor, Department of Shariah and Law, \\ Academy of Islamic Studies, \\ University of Malaya, 50603 Kuala Lumpur. \\ raihanah@um.edu.my \\ Muhammad Bashir Alkali \\ Ph.D Candidate, Department of Shariah and Law, \\ Academy of Islamic Studies, \\ University of Malaya, 50603 Kuala Lumpur. \\ mbashiralkali@yahoo.com
}

\begin{abstract}
In Islamic societies transsexuals live a life of constant negative stereotyping and presumption of guilt, despite being acknowledged by the Qur'an and Sunnah. They struggle to live their lives in peace as they are subjected to discrimination, arrests, torture, and harassment on a daily basis. This article is aimed at exploring the factors which may mitigate their dilemmas by virtue of the primary sources of Shariah. In this study, verses from Qur'ān and hadith which are used to condemn transsexuals are examined. Interpretations and opinions of several experts are also discussed in this paper. The findings reveal that transsexuality is considered to be an inherent defect and abnormality by the Will of Allah, which implies that transsexuals are not sinners and any surgical treatment to rectify physical defects is not a sinful act.
\end{abstract}

Keywords: The Qur'ān, Sunnah, transsexuality, Islamic jurisprudence, sex reassignment surgery 


\section{INTRODUCTION}

Transsexuality is considered a physical illness which has been placed on mankind as a test by Allah. In taking such a stance, basing on the Islamic view that Allah does not burden a soul with an illness which has no treatment, it is argued with the help of verses from the Qur'an and hadith that operation conducted in order to treat the physical disability of a transsexual person is not a sin. In recent times, the increasing number of transsexuals has led to an emergence of discussion on this topic. This article points out verses from the Qur'an authentic view from the Islamic jurisprudence on the matter of surgical treatment for transsexuals.

Transsexuality as a medical, psychological, and socio-cultural phenomenon has been discussed in a number of science forums in the last century. It is a birth defect; the exact cause of which is still unknown, although many biological and psychological theories have been proposed by scientists. It has been diagnosed as a gender identity disorder by early German sexologists and psychiatrists such as Richard Von Kraft Ebbing (1840-1902), Magnus Hirschfield (18681935), John Money, and Harry Benjamin (1885-1986) (Stephen W., 2010: 4-5).

Based on Euro-American studies, the term "transsexual" is used to refer to individuals who have a strong sense of their biological and physiological sex and do not believe that their gender identity corresponds to the sex they were assigned at birth - especially those who have the intention to reassign sex surgically or undergo hormone therapy (Shapiro, 2008, 138-161).

The increase in the number of transsexuals all over the world has become an important topic of discussion in legal and jurisprudential circles. In the U.S. for example, the number of sex reassignment surgeries conducted in the past four years shows that the male to female sex reassignment surgery (SRS) was one or more out of 2,500 adult male applicants (Conway 2002, 2009). There are 100,000 transsexuals in Malaysia, and it is estimated that more than one out of every 200 individuals is a transsexual in the country (Chong Lee Wei, Aziz Baharuddin et al., 2012). According to Bucar (2012: 416-434), 28,000 to 48,000 transsexuals are found in Iran, and in every 100,000 persons there are about four to six transsexuals. Hence, this is why 'Transsexualism' is becoming more visible nowadays.

Religious disputes over the legal and jurisprudential status of transsexuals are becoming increasingly difficult to ignore. Despite having diagnosed transsexuality as a gender identity disorder and accepting sex reassignment surgery as the best treatment by any standards of care, transsexuals are still facing cynicism, religious prejudices, negative attitudes, and are grappling with 
stigma, discriminations, intimidation, arrest, torture, and harassment, especially in majority Muslim countries.

Despite numerous juristic opinions, judicial decisions, and some religious verdicts (fatwa) and rulings, transsexuals continue to suffer persecution. This study on transsexuals and their acceptance in Islamic societies was conducted from the Islamic perspective by examining the primary sources of the Shariah. It seeks to remedy these problems by analyzing the main sources of Shariah, as the Prophet Muhammad (PBUH) said:

"There is no disease that Allah has created, without creating its treatment..."

(Al-Bukhari 1987, Ibn Hajar 1988)

In discussing transsexuality, the primary sources of Shariah; Qur'ān and hadith were chosen because Islam is divine and these are the roots of the Shariah which cover all aspects of human life. Further, the authenticities of all Islamic jurisprudential principles are derived from these sources. Thus, a study of transsexuality on the basis of these very foundations of the Shariah is cogent and worthwhile.

\section{SEXUALITY IN $Q U R^{\prime} \bar{A} N$ AND SUNNAH}

Allah created human beings and all other creatures into two main sexes: male and female. This is clearly mentioned in many verses of the Qur'ān such as: 13:3, 51:49, 49:13, 53:45, 75:39 and 4:1. For instance:

"People, we have created you from a male and a female..."

(Surah al-Hujurāt, 49: 13)

"And that he created pairs, the male and the female..."

(Surah al-Najm, 53: 45)

The Holy Qur'ān also acknowledges the existence of people with sexual abnormalities, queer genders, and different sexual tendencies. Although the terminology used for these categories of people is never mentioned directly in the Qur' $\bar{a} n$, there are translations and interpretations by prominent exegetes to the effect that the Qur' $\bar{a} n$ has referred to them by analogy and inference.

It is germane to mention that homosexuals (liwat) and lesbians (sihaq or musahaqah in the Arabic language) are not synonymous to transsexuals and therefore do not form part of this discussions. Atrocities against gays, supported by laws, of today are near the time of Prophet Lut. There are seven 
provisions on sodomites in the Qur'ān as follows: 11: 77-83, 7: 80-84, 21: 74, 26: $165-175,22: 43,29: 27-33,27: 56-59$. There is a typical classification of transsexuality under Islamic jurisprudence and in the following paragraphs, the types of transsexuals will be analyzed.

\section{Khuntha}

The word "khuntha" has its origin in the Arabic verb "khuntha" and the lexical meaning of it is 'soft, lean and impartial'. Khuntha literally means 'hermaphrodite' and, according to Islamic jurisprudence, it refers to either a person who has only one genital in his/her body which is covered by a layer of skin or who has both male and female sexual symptoms as defined by Jurjus (1996): "Khuntha is a person with both male and female genitals". Ibn Qudāmah in al-Mughni also defined khuntha as "a person with an opening in place of a sexual organ from which he urinates" (Qudāmah, 1984: 462).

Muhammad Hashim Kamali, with the agreement of classical Islamic jurists, points out that khuntha ghayr mushkil is a person who has both masculine and feminine sexual symptoms, but one of which is dominant. In other words, this is a woman with masculine tendencies or a man with feminine tendencies and it is easy to determine their rights according to rules of fiqh. While the problematic khuntha as those whose sexes are indeterminably combined or lacking symptoms (Kamali, 2011: 2).

The problem of khuntha mushkil (problematic hermaphrodite) is now solvable with modern medical technology which examines beyond the physiological function of genitals as it looks into the composition of sex chromosomes as well as testosterone, etc. (Haneef, 2011: 98-107). Surgical treatment is not considered as "sex change" in khuntha, whether on those who have only one genital which is covered with a layer of skin, or on those who have both male and female genitalia. In the first case, surgery is performed to reveal the real sex, and in the second case medical surgery is performed to remove one of the genitals in order to enforce the dominant genital. In this situation, a khuntha will be turned into one sex-male or female-and be able to live a normal life.

\section{Mukhannath}

According to Ibn Manzūr in Lisān al-'Arab, the word mukhannath has its origin in the Arabic verb khanatha which lexicographically or etymologically means 'folding back the mouth of a water skin for drinking'. Later, the word 
mukhannath was defined by lexicographers, such as Al-Zabidi in Taj al-arus, as a man who imitates women in softness and tenderness of voice. Mukhannath generally means 'effeminate', without any difference between intentional and unintentional behavior, and does not refer to transvestism (Rowson, 1991; 671693).

In contemporary jurisprudence, mukhannath literally means a man whose voice tone resembles that of a woman's (Haneef, 2011: 98-107). It refers to those who are anatomically male or female, but their behavior and inherent tendencies are the opposite of their assigned gender (Winter, 2008: 668-670). In the early times of Islam, a male mukhannath had to be without any arousal for women in order to be allowed to enter women's private places as a servant; they were allowed in harems and other feminine palaces because of this (Rowson, 1991: 675). The word mukhannath is not mentioned in the Qur'an, as well the words khuntha, although these terms are traditionally used in legal scholastic literatures.

There is considerable evidence of the positions of mukhannathun or effeminates in pre-Islamic societies. They have played prominent roles in the development of music at that time, especially in Mecca and Medina. They also acted as marriage brokers and go-betweens in early Islam (Rowson, 1991: 675). According to Faris Malik, the Holy Qur'ān does not prohibit the use of these individuals as passive sex partners, household servants, or harem guards because they were not considered males (Malik, 2003: 1). Islamic classical jurisprudence has identified a set of special rules and regulations for these individuals and pre-modern communities have accepted them as a part of their societies.

\section{3. 'Aqīm}

The existence of the other sort of gender that Qur'ān clearly acknowledges is 'aqìm, which means 'barren and unproductive'. Literally it means 'without any useful results', and biologically it refers to barren land or soil and trees or plants that do not produce fruit or seeds (Longman Dictionary). ${ }^{1}$ Jurisprudentially it refers to those who are neither male nor female (Malik, 2003: 1) whom are known as khuntha in classical and modern jurisprudence.

\section{TRANSSEXUALITY IN QURANIC PRINCIPLES}

Many issues are mentioned in the Qur'ān like adultery, stealing, blood money, and murder, but many modern issues are not mentioned specifically, such as

Biber, Johansson et al., 1999, Longman Dictionary, the word " "aqim". 
homosexuality, fertilization, and simulation in particular. Since the Qur'ān is inspiring words of revelation and has deep and profound implications, it is open to interpretation and many commandments may be inferred. Transsexuality is one of the new issues in modern times that has not mentioned in the Quran and old jurisprudential texts.

Since there are many translations of the Qur'ān and sometimes some words are variously translated, this study is an attempt to examine the different translations referring to transsexuality.

There are two verses in the Qur'ān referring to gender variants:

"To Allah belongs the kingdom of the heavens and the earth. He creates what he will. He gives females to whom he will and males to whom he will..."

(Surah Ash-Shura, 42: 49)

And 'or he mingled them, males and females, and he make the barren whom he will. Lo! He is knower, powerful'

(Surah Ash-Shura, 42: 50)

There are considerable points in these two verses that should be reflected on. The Holy Qur'ān wants to show Allah's power in creation in these two verses.

Therefore, the translation and interpretation of this phrase to "He bestows female on whom he will and He bestows male on whom he will" as offspring and children or daughter and son is more considerable, as some translators did: such as Farid, Shakir, Asad, Abdullah Yusuf Ali and Pickthall. The translation of this phrase to "He prepares for whom He wills female, and He prepares for whom He wills male", is closer to the style and whole concept of the two verses referring to the kind of creation, as expressed by Faris Malik and Seyyed Sikandar Shah Haneef.

Starting the second verse with ' $A w$ ', meaning 'or', as a conjunction in Arabic language, this verse is a continuation of the previous one. Following the translation and interpretation of 'Inathan wa Alththukoora' as daughter and son in the first verse, the phrase 'Au uzawwejuhum thukranan wa Inatha has been translated as 'He bestows both males and females' by Yusuf Ali, and 'He gives both male and female' by Asad. But, the word 'yuzawwijuhum' doesn't mean 'bestow or give' in Arabic. It was translated as 'He couples them, both males and females' by Qarib. But, since these two verses explicitly refer to two sorts of genders in the first verse, and refer to other kinds of gender in next part of the second verse, the word 'yuzawwijuhum' does not mean coupled or married, it 
means mingled or mixed together, as Pickthall translates: 'He mingles both male and female' (Pickthall, 2011), or 'He makes them of both sorts' (Shakir).

According to the literal translation of these verses the phrase ' $A w$ yuzawwijuhum thukranan wa Inatha' refers to another sort of gender which is a combination of male and female. This combination can be physically a khuntha, with both male and female genitals, or it can be psychic and mental, referring to persons whose gender identity is exactly the opposite of the physical sex organs of the body; the same as mukhannath in ancient times and traditional jurisprudence are known as transsexuals in modern time.

In the last phrase in Pickthall' translation - 'and He makes barren whom He wills' - the Qur'ān introduces the other sort of gender known as 'aqim.

There are some important points in these verses: firstly, the aim of these verses was to show Allah's power in creation. For example, the first verse explicitly placed emphasis on this subject. Secondly, we believe that the Qur'ān was revealed in the most eloquent style the Arabic language has known. So, if the purpose of these verses was about the bestowing of children to someone; by God, it could have used the word ' $I b n$ ' or ' $U k h t$ ' for son and daughter, instead of male and female. However, the Qur' ān uses the words 'Inathan wa Ath-thuküra' with reference to human sexuality. So, it means: "He bestows upon whom He will the masculine gender and He bestows upon whom He will the feminine gender."

Thirdly, according to the style of these verses, the Qur'ān describes the different sorts of gender very wisely. Finally, since 'what He wills' is repeated in every part, the Qur'ān intends to emphasis that these people are created according to Allah's will, not as a result of a mistake. So, they should not be considered sinners and shameless people due to their sexual abnormality. Above all, the Qur'ann intends to make us aware of the existence of these people as a sign of Allah's creation and make us conscious of their rights.

\section{TRANSSEXUALITY IN SUNNAH/ḤADITTH}

In addition to the verses of the Holy Qur'ān, there are two famous hadith (Traditions) of Prophet Muhammad (PBUH) related to this subject, narrated in many books of Islamic scholars such as Ibn Majah, Al-Nisaei, Al-Tirmidhi, Al-Bukhari, Suyuthi and Abu Dawud. For instance, the hadith number 773 in Sahih Bukhari, volume 7, which states that:

"The Messenger of God, peace be upon him, cursed men who simulate women, and women who simulate men..." 
Although this hadith is used by most opponents to condemn transsexuality, major Islamic scholars have argued that it refers to cross-dressers and transvestism. Similarly, Ibn Majah, Bukhari, and Abu Dawud expressed that simulation in this hadith refers to imitation in dress. However, some scholars have included imitation in terms of speaking, walking, women's ornament, movement, and softness in speech, such as Ibn Hajar. Accordingly, it does not include transsexuals and real mukhannathun who behave according to their true nature and gender.

In other words, the curse of the Prophet (PBUH) refers to those who habitually and deliberately imitate the appearance and external behavior of the opposite sex, not transsexuals who behave according to their gender identity as affirmed by Malik and Haneef.

The other prophetic hadith that has been debated for condemning transsexuality was stated: ${ }^{2}$

"It is narrated on the authority of Ibn 'Abbās; 'The Prophet peace be upon him, cursed the effeminate men, who are males, and the male-pretenders, who are women, and he said: Evict them from your houses, and the Prophet, peace be upon him, evicted suchand-such and 'Umar evicted such-and-such..."

This hadīth was also narrated by many Islamic scholars like Ibn Majah, Al-Bukhari, Al-Tirmidhi, Ibn Hanbal, and Abu Dawud. According to these scholars, the mukhannathun in this hadith generally refers to men who imitate women in clothing, speech, behavior, mannerisms, and appearance, and 'AlMutarajjilat' -'the male-pretender women" - refers to women who imitate men in behavior, mannerisms, and appearance. Although this hadith was used to condemn transsexuals by some contemporary scholars, two points raised that need further discussions.

The first point is that the curse of Prophet Muhammad (PBUH) does not directly refer to mukhannathin and mutarajjilat. Rather, it is directed at normal men and women who intentionally behave like the opposite sex. If the curse of the Prophet (PBUH) is directed at mukhannathin and al-mutarajjilat, there is no need to use the terms "men" and "women". These words have been repeated to emphasize and stress on the fact that the curse of the Prophet (PBUH) is not directed at mukhannathin and al-mutarajjilat, but refers to normal men and women who imitate the opposite sex.

$2 \quad$ Sahih Bukhari, Volume 6, No: 774 
The second point is, assuming that the curse of the Prophet (PBUH) is directed at mukhannathin and mutarajjilat; it still does not refer to transsexuals. According to Ibn Hajar, there are two groups of mukhannathun: the first group consists of those who imitate the opposite sex in clothing, speaking, walking, behavior, and mannerisms according to their innate and inherent nature. They are not considered sinners and should not be blamed or punished because their behavior is natural. They are transsexuals, which according to Ibn Hajar, the curse of Prophet (PBUH) does not apply. The second group consists of those who imitate the opposite sex in appearance, clothing, speech, and behavior deliberately with erotic tendencies. In fact, they are men and women deviating from their fitrah. These are the ones the Prophet (PBUH) cursed and they are sinners, thus culpable.

In the light of the above mentioned ahadìth, Islamic scholars have differed on the topic of transsexuality.

Most opponents relied on these ahadith to condemn transsexuals, but the curse in both does not include natural mukhannathun. Rather, the curse refers to men and women who deliberately imitate the opposite sex. So transsexuals are natural mukhannathun who behave according to their fitrah. Hence, if their sexual abnormality can be remedied by medical treatments, conducted by professional physicians, they should not be prohibited according to Islamic ethics and their surgical treatment should not be considered as a manipulation of Allah's creation.

There are other hadith that support the treatment for these individuals. As the Prophet Muhammad (PBUH) said:

"Nine things have been excused for my ummah (nation); mistakes, forgetfulness, forced actions, what they do not know, what they cannot tolerate, what is distress for them, jealousy, divination, and tempting ideas about people until it is not said..." 3

According to this hadith, the permissibility of sex reassignment surgery can be inferred from the following two points. First, with regard to the content of this hadith, if a person misbehaves out of valid ignorance, he or she should not be reprimanded. In other words, if someone does something that he or she doesn't have knowledge of, they should not be punished. There is no reason to oppose sex reassignment surgery as a treatment for transsexuals according to Islamic law, sex change operation is permissible.

3 Muhammad Ibn Ya'qūb al-Kulaynī, Ușūl al-Kāfì, vol. 2, 463, no. hadīth 2; Ibn Babawayh (al-Shaykh al-Saduq), al-Khisal, Man la Yahduruhu al-Faqih, vol. 2, 417; Muhammad Bāgher Majlisi, Bihar al-Anwār, vol. 2, 280. 
Secondly, according to this hadith, in the case of emergency, such as when something is intolerable and one has no choice but to do the unlawful, then no punishment should be imposed on him. In Islamic law, necessity dispenses prohibition. Accordingly, when a person is suffering from a severe physical and psychological disorder, sex reassignment surgery would be lawful and permissible as a necessity.

To conclude, it can be said that sex reassignment surgery as a medical treatment for transsexuals under trustworthy physicians should not be unlawful as there are some verses and ahadith which encourage Muslims to seek treatment for ailments, as Abu Hurayrah narrates that the Prophet Muhammad (PBUH) said:

"Cure your ailment; Allah has never created a disease but created its treatment, except death..." 4

Furthermore, Islam, as the best guide for humanity, is in line with human nature and it is aware of people's limits, never burdening them. As the Qur'ān says:

"God makes no soul responsible for what is beyond its capacity"

(Surah al-Baqarah, 2: 233)

Furthermore, Islam never advocates hardship and adversity for people, and forbids any persecution, harm, or torture. It always encourages forgiveness and leniency. As Allah says:

"And hath not laid upon you in religion any hardship"

(Surah al-Hajj, 22: 78)

"Allah wants ease for you and does not want hardship for you"

(Surah al-Baqarah, 2: 185)

\section{THE ISLAMIC OPINION ABOUT SEX REASSIGNMENT SURGERY}

Medical science and surgical technological developments are creating the grounds for new debates and discussions. "Sex reassignment surgery" is one of the newly disputed methods eliciting global discussions today in legal and moral philosophy.

According to the standards of care presented by Harry Benjamin International Gender Dysphoria Association, transsexuality is an illness rooted

4 Șah̄ịh al-Bukhārī, M. (1959), Uzbekistan, Egyptian Press of Mustafa Al-Babi AlHalabi, vol. 7, Book 71, no. hadìth 582. 
in biological factors and since changing genitalia is easier than changing gender identity, sex reassignment surgery has been recognized as the effective treatment for gender identity disorders. This is because, unlike all ineffective psychological therapies, sex reassignment surgery provides an unambiguous gender for transsexuals. (Shapiro, 2008: 138).

It is the incongruity between the sex naturally assigned at birth and the gender identity among transsexuals - and not the satisfaction of their sexual desires - that causes some of these individuals to demand a sex change through medical surgery.

The problems of these individuals are now solvable with advances in medical science and technology beyond the physiological function of genitalia, as it looks into the composition of sex chromosomes, gonads, as well as testosterones etc. (Haneef, 2011: 98-107). Although sex reassignment surgery has been accepted for khuntha as a medical treatment by most Islamic scholars, it is considered a manipulation in God's creation and has been condemned by most contemporary jurists.

The other reason for religious disputes about sex reassignment surgery is an argument raised in some verses of the Qur'än and ahadith. There is a general belief among Muslims that we must be content with what Allah has intended for us and should never protest or try to change what Allah created. The basis of this belief lies in verse 119 of Surah al-Nisā', which is the most controversial verse against sex reassignment surgery as a treatment for transsexuals. According to this verse, some scholars argued that any change in Allah's creation is forbidden (Seyyed Sadiq Shirazi, Yusuf Al-Qaradawi, and Ahmad Muhammad Kana'n). The council of the Islamic Fiqh Academy of the Muslim World League, in a major fiqh assembly regarding sex change operations in Mecca, from the $19^{\text {th }}$ to the $26^{\text {th }}$ of February, 1989, stated the following:

"The change is not legally permissible if the person (male or female) has complete male or female sex organs. This is because this person would be seeking to change Allah's creation, which is forbidden by Allah Almighty as in the verse in which Allah reports Satan as saying: ...and surely I will command them and they will change Allah's creation..."

(Surah al-Nisā', 4: 119)

For a better understanding of the meaning of verse 119 of Surah al-Nisā', one needs to refer to the three previous verses. Verse 116 of Surah al-Nisā' refers to the unforgivable sin of polytheism to God (shirk): 
"Surely Allah does not forgive that anything should be associated with Him, and He forgives what is besides this to whom he pleases; and whoever associates anything with Allah, he indeed strays off into a remote error..."

(Surah al-Nisā', 4: 116)

Verse 117 explains that shirk is the following of Satan by going astray; getting away from Allah's worship and indulging in idolatry. The verse reads as follows:

"They do not call besides him on anything but idols, and they do not call on anything but a rebellious Satan..."

(Surah al-Nisā', 4: 117)

Verse 118 of this Surah says:

"Allah has cursed him; and he said: Most certainly I will take an appointed portion from thy servants..."

(Surah al-Nisā', 4: 118)

In this verse, in retaliation for being damned by Allah, Satan said: "I will take a certain proportion of your (God's) slaves and will mislead them." Eventually, verse 119 describes how Satan misleads people when it says:

"And most certainly I will lead them astray and excite in them vain desires, and bid them so that they shall slit ears of the cattle, and most certainly I will bid them so that they shall alter Allah's creation; and whoever takes Satan for a guardian rather than Allah, he indeed shall suffer a manifest loss..."

(Surah al-Nisā', 4: 118-119)

The change in Allah's creation as expressed in this verse entails that any change in creatures is done with sinister motive. Examples of physical and external changes are the traditional cutting of the ears of cattle and removal of the eyes of animals, while spiritual changes are to mislead people and abandon servitude to God. However, both types of changes are in the direction of the devil's goals and can lead to harm.

Therefore, any changes done with sinister motive are indecent and illegal. This verse narrates that at the time of ignorance, when a camel breeds more than once, they cut or slot its ear or remove its eye and endow them for the idols. They devote the camel to idols and would neither slaughter nor ride on it. These practices are forbidden by the Qur'ān as they are tantamount to making 
changes in God's creation unlawfully and following Satan. The prohibition is not for only cutting off the ear or removing the eye of cattle, but it is prohibited due to the sinister motives behind these acts. The purpose behind the creation of animals is to eat their meat and use them for riding or carrying heavy loads. These kinds of beasts are created for men to use them in order to have the ability to pray and worship Allah. Mullá Muhsin Fayḍ Kashani said that: ${ }^{5}$

"Cutting off the camel's ear is not considered just as the devil's work, but if you cut off the ear as a sign of sanction or, as the idol worship, it is forbidden..."

(Kashani, 1988: 239).

Moreover, if one holds to the argument that this verse prohibits any change to Allah's creation, then most of our daily activities would be illegal. Such activities include turning wheat into flour, wood into charcoal, and all other similar transformations. Others include digging tunnels in the mountains, occupying the forest, entering to the depths of the earth for oil and so many other artificial creations. Thus, any change in Allah's creation is not forbidden and not considered as following the Satan except when it leads one to go astray.

Furthermore, according to the most erudite exegetes on this subject, such as Razi (1938), Tabatabaei (1971), and Al-Tabari (1978), the word 'creation $(\mathrm{khalq})$ ' in this verse means religion and order $(\mathrm{hukm})$. Hence, the change in God's creation here means the change in God's order or change in God's religion on which the Fitrah is based. The purpose of these changes comes from the Fitrah itself. Their argument on verse 30 of Surah al-Rum is as follows:

"Then set your face upright for religion in the right state- the nature made by Allah in which He has made men; there is no altering of Allah's creation; that is the right religion, but most people do not know..."

(Surah al-Rūm, 30: 30)

Therefore, this verse is not considered as a strong reason and clear proof for prohibiting sex reassignment surgery or other physical and medical treatments. It states a general rule that anything contrary to God's commands and any changes made with evil motive are forbidden.

Therefore, if sex reassignment surgery is done according to medical standards under the supervision and care of professional physicians, it would be

5 Kashani, M.F. (1418), Tafsir Safi, Iran, Qum, Markaz-e Entesharat-e Tablighat-e Islami, vol. 1, 239. 
consistent with legal principles and would not be contrary to Islamic morals. Indeed, not only it is permissible for transsexuals to undergo surgery to reveal their true sexual identity, according to Tantawi, it is obligatory to do it when it is considered a treatment (Skovgaard-Petersen, 1995: 12). However, it is forbidden to do it just to satisfy a passing fancy.

\section{HOMOSEXUALITY-RELATION WITH SEXUAL ORIENTATION OF TRANSSEXUALS}

Although homosexuality is not a form of transsexuality, it is however worthy of mention because some transsexuals indulge in it.

Sexual intercourse between males is called liwat in Arabic and lawa't in Persian (derived from the story of Lut). The word encompasses both modern day gays and lesbians (sihaq or musahaqah) There are seven references about the condemnation and punishment of sodomy in the Qur'ān (11:77-83, 7:80$84,21: 74,26: 165-175,22: 43,29: 27-33,27: 56-59)$. According to these verses, homosexuality is a different form of adultery and is called the worst sin in Islam, punishable by stoning. It is also prohibited by the Sunnah as there are several ahadith on its description and chastisement.

Although there is a consensus on the prohibition of same sex intercourse in Islamic jurisprudence, opinions vary among different Islamic schools of thought about the punishment for homosexuality. As stated by the modern Islamic scholar, Yusuf al-Qaradawi:

"The jurists of Islam have held different opinions concerning
the punishment for this abominable practice. Should it be the
same as the punishment for zina, or should both the active and
passive participants be put to death? While such punishments may
seem cruel, they have been suggested to maintain the purity of the
Islamic society and to keep it clean of perverted elements..."

(Rehman. j and Polymenopoulou. E, 2012: 12)

According to the Hanafi school of thought, same sex intercourse is not considered adultery and according to most Hanafi scholars, is not punishable by death except for a second offense - at the judge's discretion. In the opinion of the Maliki School, any same sex intercourse should be punished as adultery and given the death sentence. The Shafi'i school of thought has differentiated between married and unmarried persons. A married person who commits the same sex act would be punished by stoning to death, while an unmarried person is to be punished by flogging. However, according to the Ja'fari school, 
anyone who has committed same sex intercourse - married or unmarried - is punished as an adulterer (Bello, 2012).

Unlike the existence of a clear punishment for adultery or zina in the Qur'àn, there is no clear decree on punishment for homosexuality and this has led to the application of different Islamic rules for homosexuality in Islamic societies. Homosexuality is punishable by death in Islamic countries such as Iran, Saudi Arabia, Sudan, Mauritania, Yemen, Southern Somalia, Afghanistan (under the Taliban), and in Iraq (under Saddam Hussein in 2001). In Muslim majority countries, homosexuality is a crime punishable by death (public stoning (rajam), jail, lashing, or fines. These countries include Qatar, Bahrain, Maldives, Bangladesh, Malaysia, and Algeria. But homosexuality is not forbidden by law in some Islamic majority countries like Egypt, Jordan, Mali, and Turkey. This is as a result of the campaign for gay rights by international human right organizations as spearheaded by the United Nations Human Rights Committee which declared that laws against homosexuals violate the right of privacy contained in the Universal Declaration of Human Rights (Rehman and Polymenopoulou, 2012: 4).

\section{CONCLUSION}

This study was aimed at examining transsexuality from the Islamic perspective with particular emphasis on the two primary sources: the Qur'an and the Sunnah. The study examined various translations and interpretations of the Qur'ān and ahadith. The findings reveal that transsexuality as a gender identity disorder is an inherent sexual abnormality and the Qur'ān explicitly acknowledges the existence of these people (Qur'ān, 42: 49-50). Sex reassignment surgery is recognized as an effective treatment for transsexuals, as Islam always encourages Muslims to seek treatment for their illnesses. This surgery is just like any other medical treatments and should not be considered as a deliberate act to change Allah's creation. As can be seen in the above explanation, change in Allah's creation means an attempt to mislead His servants, which is prohibited by the Qur' $\bar{a} n$ (30: 30). Also, the curse of the Prophet (PBUH) in His two famous ahadith affects men and women who have imitated the opposite sex deliberately, not transsexuals who suffer from a severe gender identity disorder. If these individuals are not allowed treatment, they will be vulnerable to societal afflictions and adversity as well as sexual misconduct which is against Islamic morals. So, if sex reassignment surgery is done according to medical standards - diagnosed and performed under the supervision of trustworthy professional physicians - it would be in line with Islamic rulings and therefore a necessary treatment (Rehman and Polymenopoulou, 2012: 22- 
23). In conclusion, it is cogent to mention that this paper represents the use of analogical deduction ( $q \dot{i} \bar{y} \bar{a} s)$ by Islamic scholars to develop the Shariah to be in tune with all times.

\section{REFERENCES}

Al-Qardawi, Y. (1997). The Lawful and the Prohibited in Islam, Islamic Books. El Falah.

Al-Thabari, I. J. (1978). Jami ‘ al-Bayān fì Tafsīr al-Qur'ān. Bayrūt: Dār al-Fikr.

Anthony, Dick \& Thomas L. Robbins (1978). "The Effect of Detente on the Growth of New Religions," Understanding the New Religions, ed. Jacob Needleman \& George Baker. New York: The Seabury Press, 80-100.

Bello, Shafi'i Abdul Azeez (2012). "The Punishment of Homosexuality in Islamic Contemporary World: Malaysia, Iran, Pakistan and Saudi Arabia as a Case Study", 5, https://ssrn.com/abstract=2183622 or http://dx.doi. org/10.2139/ssrn.2183622

Biber, D., S. Johansson, G. Leech, S. Conrad, E. Finegan \& R. Quirk (1999). Longman Grammar of Spoken and Written English. Harlow, United Kingdom; MIT Press.

Bucer, Elizabeth M. (2010). "Bodies at the Margins: The Case of Transsexuality in Catholic and Shia Ethics," Journal of Religious Ethics, vol. 8, no. 4, 601-615.

Cannon, J. R. (2008). The Bible, Christianity, and Homosexuality Justic Cannon. USA: Justin Cannon.

Chang Lee Wei, Azizan Baharuddin, Raihanah Abdullah, Zuraidah Abdullah \& Kathleen Por Chhe Ern (2012). "Transgenderism in Malaysia," Journal of Dharma, Dharmaram Journal of Religions and Philosophies, vol. 37, no. $1,79-96$.

Conway, L. (2002). "How frequently does Transsexualism occur," http://www. lynnconway.com, accessed on 3 May 2009.

Hanbal, A. I. (1993). Musnad Imam Ahmad. Bayrut, n.p.

Haneef, S. S. S. (2011). "Sex Reassignment in Islamic Law: The Dilemma of Transsexuals," International Journal of Business, Humanities and Technology, vol. 1, no. 1, 98-107.

Hendricks, M. (2010). "Islamic Texts: A Source for Acceptance of Queer Individuals into Mainstream Muslim Society," The Equal Right Review, 31-51. 
Ibn Hajar, A. (1988). Fath al-Bari bi Sharh Sahih al-Bukhari, 2 $2^{\text {nd }}$ ed. Dār alRayyan.

Jami, H. (2005). "Condition and Status of Hijras (transgender, transvestites etc) in Pakistan. Sexualities, Genders and Rights in Asia," (1st International Conference of Asian Queer Studies Retrieved September).

Jurjus, J. (1996). Mu 'jam al-Muștalaḥāt al-Fiqhiyyah wa-al-Qānūnīyah. Lebanon, Beirut, Charikat Al Alamiya Lil Kitab.

Kamali, M. H. (2011). “Transgenders and Justice in Islam," New Straits Times.

Kugle, S. S. a.-H. (2010). Homosexuality in Islam; Critical Reflection on Gay, Lesbian, and Transgender Muslims. Oxford, UK: One world Publications.

Malik, F. (2003). "Queer Sexuality and Identity in the Qur'an and Hadith," http://www. Well. Com/user/aquarius/Qur'annotes. htm., accessed 14 June 2017.

Pickthall, M. M. (2001). The Glorious Qur'an: The Arabic Text with a Translation in English. Ttq Inc. United Kingdom.

Polat, A., S. Yuksel, A. G. Discigil \& H. Meteris (2005). "Family Attitudes Toward Transgendered People in Turkey: Experience from A Secular Islamic Country," The International Journal of Psychiatry in Medicine, vol. 35, no. 4, 383-393.

Qudamah, I. (1984). al-Mughni. Riyāḍ: al-Maktabah al-Hadīthah.

Razi, F. a. 938, (1357). al-Tafsir al-Kabir. Qāhirah: al-Matba'ah al-Bahiyyah, 140-141.

Rehman, J. \& E. Polymenopoulou (2012). "Is Green a Part of the Rainbow? Shari'ah, Homosexuality and LGBT Rights in the Muslim World," Shari'ah, Homosexuality and LGBT Rights in the Muslim World (October 10, 2012).

Rida, M. R. \& M. Abduh (1980). Tafsir al-Manar. Bayrūt: Dār al-Ma‘rifah.

Riskuwa A. S., (2003). Vice Chancellor, Usman Daffodil University, Sokoto, the Glorious $27^{\text {th }}$ National Qur'anic Recitation Competition in Gusau, Nigeria.

Rowson, E. K. (1991). "The Effeminates of Early Medina," Journal of the American Oriental Society, vol. 111, no. 4, 671-693.

Sahīh al-Bukhārī, M. (1959). Uzbekistan: Egyptian Press of Mustafa Al-Babi Al-Halabi.

Sanders, P. (1991). Gendering the Ungendered Body, Women in Middle Eastern History. New Haven and London: Yale University Press. 
Shakir, M. S. (2001). The Glorious Qurán: with Translation and Transliteration. Lahore, Pakistan: Raheel Publication.

Shapiro, J. (2008). "Same-sex Cultures and Sexualities: An Anthropological Reader", Published Online: 21 APR 2008, vol. 6.

Skovgaard-Petersen, J. (1995). "Sex Change in Cairo: Gender and Islamic Law," Journal of the International Institute, vol. 2, no. 3.

Stephen, W. (2010). "The brief history of transgender issues," Gardian, 11.49 BST,http://www.theguardian.com/lifeandstyle/2010/jun/02/brief-histor y-transgender-issues, accessed on 2 June 2010.

Tabatabai, M. H. (1971). al-Mīzān fì Tafsīr al-Qur'ān. World Organization for Islamic Services (WOFIS) (1st to 13 th volumes), Tawheed Institute Australia LTD. (14th and 25th to 30th volumes).

Tehrani, M. S. (1988). Tafsir al-Furqan. Iran, Qum, Shokraneh.

Ṭūsī, M. i. a.-H. \& H. a.-M. Kharsān (1985). Tahdhīb al-Ahkām fì Sharh alMuqniāh li al-Shaykh al-Mufid. Dār al-ḍ̂ā'.

Winter, S. (2008). "Sexual Identity: Effeminacy Among University Students," Archives of Sexual Behavior, vol. 37, no. 4, 668-67. 